\title{
PENGARUH APLIKASI PUPUK NPK TERHADAP PERTUMBUHAN DAN HASIL TANAMAN SELEDRI (Apium graveolens L.) PADA MEDIA GAMBUT
}

\author{
Badrul Ainy Dalimunthe, Widya Lestari \\ Program Studi Agroteknologi, Fakultas Sains dan Teknologi, Universitas Labuhanbatu \\ e-mail : badrulainy@stiper-labuhanbatu.ac.id
}

\begin{abstract}
Celery (Apium graveolens L.) is a vegetable plant that has long been known in Indonesia. Celery plants have many benefits. Celery plants come from Europe, especially in the Mediterranean region around the Mediterranean Sea. This plant spreads to the Plains of China, India, Central Asia, Ethiopia, South and Central Mexico and the United States the influence of NPK fertilizer on the growth and yield of celery plants on peat media. This research was conducted on Kenanga Street, Teluk Panji IV, Kampung Rakyat Subdistrict, Labuhan Batu Selatan Regency, at an altitude of $\pm 23 \mathrm{~m}$ above sea level. This activity will be carried out from February 2019 to May 2019. The design used is a randomized single factor group design that is with NPK fertilizer dosage: Treatment P0: (control), P1: (5 g / plant) P2: (10 g / plant ). The parameters observed were plant height $(\mathrm{cm})$, number of leaves (strands), number of tillers, harvest weight $(\mathrm{g})$. From the results of data analysis it was found that the effect of NPK Phonska fertilizer $(15 ; 15 ; 15)$ can increase the growth of celery plant. The highest plant height $(11.93 \mathrm{~cm})$ Number of leaves (6.5 strands) Number of tillers (8.66) Weight of harvest $(17.5 \mathrm{~g})$. NPK Phonska fertilizer $(15 ; 15 ; 15)$ is recommended with a dose of P2: $(10 \mathrm{~g} /$ plant $)$.
\end{abstract}

Keywords : Celery (Apium graveolens L.), NPK, Peat Soil

\section{PENDAHULUAN}

Tanaman seledri (Apium graveolens L.) berasal dari Eropa, khususnya di wilayah Mediterania sekitar Laut Tengah. Tanaman ini menyebar ke Dataran Cina, India, Asia Tengah, Etiopia, Meksiko Selatan dan Tengah serta Amerika Serikat. Di Indonesia pertanaman seledri lebih banyak ditanam di daerah pegunungan terutama di daerah Pacet, Pangalengan, Cipanas, Lembang (Jawa Barat) dan Berastagi, Kabanjahe (Sumatera Utara) sebagai usahatani rakyat setempat (Soewito, 1991).

Seledri merupakan tanaman sayuran sudah lama dikenal di Indonesia. Tanaman seledri memiliki banyak manfaat. Daun dan tangkai daun seledri dapat digunakan sebagai campuran sup dan bahan makanan berkuah lainnya.
Seledri juga dapat digunakan sebagai tanaman biofarmaka, yaitu untuk mengobati berbagai penyakit seperti demam, flu, gangguan pencernaan, limpa dan hati (Dalimartha, 2005).

Dalam program penelitian dan pengembangan hortikultura di Indonesian pada Pusat Penelitian dan pengembangan (Puslitbang). Hortikultura sampai 2003/2004, ternyata tanaman seledri belum mendapatkan prioritas penelitian, baik sebagai komoditas utama, potensial maupun introduksi (Sutrisna et al., 2005).

Meskipun pada dasarnya prospek seledri sangat cerah, baik di pasaran dalam negeri (domestik) maupun luar negeri sebagai komoditas ekspor, namun pembudidayaan seledri di Indonesia yang belum dikelola secara komersial dan 
diantaranya dapat merujuk pada data dari Badan Pusat Statistik (BPS) tentang hasil survey pertanian tanaman sayuran di Indonesia pada tahun 2008, ternyata belum ditemukan data luas panen dan produksi seledri secara nasional.

Budidaya seledri tidak hanya pada kebun yang luas, tetapi pada lahan yang sempit seperti pada lahan perkarangan masih dapat diusahakan dalam pot atau polybag. Pemanfaatan lahan untuk membantu bagi kebutuhan hidup manusia perlu pengolahan yang lebih lanjut. Oleh sebab itu diperlukan suatu kebijakan atau keputusan pada suatu penggunaan lahan.

Menurut Wahyunto \& Subiksa (2011), pemanfaatan lahan gambut sebagai lahan pertanian termasuk perkebunan memerlukan perhatian khusus dan manajemen pertanian yang tepat. Pemanfaataan sumberdaya alam berupa lahan rawa gambut secara bijaksana perlu perencanaan yang teliti, penerapan teknologi yang sesuai dan pengelolaan yang tepat (Wahyunto \& Heryanto, 2005). Oleh Karena itu menanam seledri dalam pot atau polybag, selain kondisinya dianggap lebih mudah dikontrol juga dapat difungsikan sebagai tanaman hias.

Penggunaan pupuk di dunia terus meningkat sesuai dengan pertambahan luas areal pertanian, pertambahan penduduk, kenaikan tingkat intensifikasi serta makin beragamnya penggunaan pupuk sebagai usaha peningkatan hasil pertanian. Para ahli lingkungan hidup khawatir dengan pemakaian pupuk kimia akan menambah tingkat polusi tanah akhirnya berpengaruh terhadap kesehatan manusia (Lingga \& Marsono, 2000).

Oleh karena itu diperlukan penggunaan pupuk organik yang menggantikan penggunaan pupuk anorganik yang efisien dalam meningkatkan ketersediaan unsur hara (N,P, dan K), salah satunya adalah pupuk NPK Phonska (15:15:15). Pupuk NPK Phonska (15:15:15) merupakan salah satu produk pupuk NPK yang telah beredar di pasaran dengan kandungan Nitrogen $(\mathrm{N})$ $15 \%$, Fosfor (P2O5) 15\%, Kalium (K2O) $15 \%$, Sulfur (S) $10 \%$ dan kadar air maksimal 2\%. Pupuk majemuk ini hampir seluruhnya larut dalam air, sehingga unsur hara yang dikandungnya dapat segera diserap dan digunakan oleh tanaman dengan efektif (Kaya, 2013).

\section{METODE PENELITIAN}

Penelitian ini menggunakan metode Rancangan Acak Kelompok (RAK) faktor tunggal yaitu dosis pupuk NPK PHONSKA, adapun dosis tersebut adalah :

Faktor Dosis Pupuk NPK Phonska terdiri dari 3 taraf yaitu:

P0 = Tanpa Perlakuan ( Kontrol )

P1= Pupuk NPK Phonska 5 g/bibit

P2= Pupuk NPK Phonska $10 \mathrm{~g} / \mathrm{bibit}$

Jumlah ulangan : 2 ulangan

Jumlah perlakuan $: 2$ perlakuan

Jumlah polybag : 15 polybag

Jumlah tanaman keseluruhan : 30 tanaman

\section{Metode Analisis Data}

Metode yang digunakan yaitu data yang diambil dari tinggi tanaman $(\mathrm{cm})$, jumlah daun (helai), jumlah anakan dan berat panen $(\mathrm{g})$. Kemudian data di input dan di rata-ratakan dengan Microsoft Excel 2010 dan di presentasikan dalam bentuk tabel. Sampel diambil dari perlakuan yang diberi pupuk NPK Phonska (15:15:15) yaitu dengan dosis P0 (kontrol/tanpa perlakuan pupuk NPK), P1 (5g/tanaman) dan P2 (10g/tanaman). Pupuk NPK dengan sumber NPK Phonska 
diberikan pada saat tanaman berumur 3 Minggu Setelah Tanam (MST) sesuai dengan perlakuan yang sudah di terapkan, pemberian pupuk dilakukan 2 minggu sekali.

\section{HASIL DAN PEMBAHASAN}

Dari hasil pengamatan pada penelitian pengaruh pemberian pupuk NPK terhadap pertumbuhan dan hasil tanaman seledri (Apium graveolens L.) pada media gambut menunjukkan pengaruh nyata (Tabel $1)$.

Tabel 1. Tinggi tanaman seledri $(\mathrm{cm})$ pada ulangan I

\begin{tabular}{lrrrrrr}
\hline \multicolumn{1}{c}{ Perlakuan } & 2 MST & 4 MST & 6 MST & 8 MST & Jumlah & Rataan \\
\hline P0 (Kontrol) & 5,3 & 8,8 & 11,0 & 12,8 & 25,1 & 8,36 \\
P1 (5g/tanaman) & 6,5 & 10,8 & 11,6 & 15,1 & 28,9 & 9,63 \\
P2 (10g/tanaman) & 6,8 & 11,0 & 12,7 & 18,2 & 30,5 & 10,16
\end{tabular}

Keterangan : Data pengamatan masing-masing ulangan I dan ulangan II pada setiap pengamatan diambil nilai rata-rata per tanaman

Tabel 2.Tinggi tanaman seledri (cm) pada ulangan II

\begin{tabular}{lllllll}
\hline \multicolumn{1}{c}{ Perlakuan } & 2 MST & 4 MST & 6 MST & 8 MST & Jumlah & Rataan \\
\hline P0 (Kontrol) & 6 & 10 & 13 & 13,8 & 42,8 & 9,66 \\
P1 (5g/tanaman) & 7 & 11,2 & 15 & 19,2 & 52,4 & 11,06 \\
P2 (10g/tanaman) & 7,5 & 12,3 & 16 & 20,2 & 56 & 11,93 \\
\hline
\end{tabular}

Keterangan : Data pengamatan masing-masing ulangan I dan ulangan II pada setiap pengamatan diambil nilai rata-rata per tanaman

Dari Tabel 1 dan Tabel 2 di atas terlihat bahwa pengaruh dosis pupuk NPK terhadap pertumbuhan tinggi tanaman seledri (Apium graveolens L.) pada pengamatan menunjukkan tanaman tertinggi pada dosis pupuk NPK P2 (10g/tanaman) pada tiap-tiap minggu yaitu pada minggu ke $2: 7,5 \mathrm{~cm}$ minggu ke 4 : $12,3 \mathrm{~cm}$ minggu ke $6: 16 \mathrm{~cm}$ minggu ke 8 : 20,2 cm pada ulangan ke II. Selanjutnya untuk tanaman terendah ditunjukkan pada perlakuan kontrol Po pada tiap-tiap minggu yaitu pada minggu ke $2: 5,3 \mathrm{~cm}$ minggu ke $4: 8,8 \mathrm{~cm}$ minggu ke $6: 11 \mathrm{~cm}$ minggu ke $8: 12,8 \mathrm{~cm}$ pada ulangan ke I. Namun pengaruh perlakuan antara P0, P1 dan P2 menunjukkan berpengaruh dimana masing-masing sampel yang diamati hanya menunjukkan tinggi tanaman, namun untuk rekomendasi dalam penelitian ini pengaruh pemberian pupuk NPK dalam pengamatan tinggi tanaman yaitu P2 menunjukkan keunggulan pada dosis $10 \mathrm{~g} /$ tanaman.

Pemupukan pada tanaman seledri (Apium graveolens L.) ini dilakukan supaya bisa menambah unsur hara tanah yang masih kurang dalam tanah. Ketersediaan unsur hara merupakan salah satu faktor lingkungan yang sangat menentukan cepat lambatnya pertumbuhan tanaman. Sehingga dibutuhkan lebih banyak unsur hara esensial yang tersedia dan dapat diperoleh melalui peningkatan 
dosis pupuk. Pupuk dolomit tidak jadi diaplikasikan disebabkan setelah dilakukan pengukuran $\mathrm{pH}$ awal terhadap tanah gambut didapatkan nilai $\mathrm{pH} \quad 7.0$ yang berarti tanah gambut yang digunakan pada penelitian ini berpH normal.

\section{Jumlah Daun (helai)}

Hasil pengamatan dari jumlah helai daun tanaman dan rata-rata tinggi tanaman seledri yang dilakukan setiap 2 minggu sekali pada saat masa pertumbuhan (Tabel 3 dan Tabel 4).

Tabel 3. Jumlah daun seledri (helai) pada ulangan I

\begin{tabular}{lcccccc}
\hline \multicolumn{1}{c}{ Perlakuan } & 2 MST & 4 MST & 6 MST & 8 MST & Jumlah & Rataan \\
\hline P0 (Kontrol) & 3 & 5 & 7 & 7 & 15 & 5,50 \\
P1 (5g/tanaman) & 4 & 7 & 7 & 7 & 15 & 6,25 \\
P2 (10g/tanaman) & 4 & 7 & 7 & 7 & 18 & 6,25
\end{tabular}

Keterangan : Data pengamatan masing-masing ulangan I dan ulangan II pada setiap pengamatan diambil nilai rata-rata per tanaman

Tabel 4. Jumlah daun seledri (helai) pada ulangan II

\begin{tabular}{lllllll}
\multicolumn{1}{c}{ Perlakuan } & 2 MST & 4 MST & 6 MST & 8 MST & Jumlah & Rataan \\
\hline P0 (Kontrol) & 4 & 7 & 7 & 7 & 18 & 6,25 \\
P1 (5g/tanaman) & 5 & 7 & 7 & 7 & 19 & 6.50 \\
P2 (10g/tanaman) & 5 & 7 & 7 & 7 & 19 & 6.50
\end{tabular}

Keterangan : Data pengamatan masing-masing ulangan I dan ulangan II pada setiap pengamatan diambil nilai rata-rata per tanaman

Dari Tabel 3 dan 4 di atas dapat dilihat bahwa pada semua perlakuan P0, P1, P2 menunjukkan bahwa dosis pupuk NPK berpengaruh terhadap jumlah daun pada tanaman seledri (Apium graveolens L.). Namun dalam pengamatan ini terlihat perlakuan dengan angka terbesar pada perlakuan P1 (5g/tanaman) dan P2 (10g/tanaman) pada tiap-tiap minggu yaitu pada minggu ke $2: 5$ helai minggu ke $4: 7$ helai minggu ke $6: 7$ helai minggu ke $8: 7$ helai pada ulangan ke II dan untuk jumlah daun yang paling sedikit pada perlakuan P0 (kontrol) pada tiap-tiap minggu yaitu pada minggu ke $2: 3$ helai minggu ke $4: 5$ helai minggu ke $6: 7$ helai minggu ke $8: 7$ helai pada ulangan ke I.

\section{Jumlah Anakan}

Hasil pengamatan dari jumlah helai daun tanaman dan rata-rata tinggi tanaman seledri yang dilakukan setiap 2 minggu sekali pada saat masa pertumbuhan dapat dilihat pada Tabel 5 dibawah ini. 
Table 5. Jumlah Anakan

\begin{tabular}{lcccc}
\hline \multicolumn{1}{c}{ Perlakuan } & Ulangan I & Ulangan II & Jumlah & Rataan \\
\hline P0 (Kontrol) & 3 & 5 & 7 & 4,66 \\
P1 (5g/tanaman) & 4 & 7 & 11 & 7,33 \\
P2 (10g/tanaman) & 4 & 7 & 13 & 8,66
\end{tabular}

Keterangan : Data pengamatan masing-masing ulangan I dan Ulangan II pada setiap pengamatan diambil nilai rata-rata per tanaman

Pada Tabel 5 diatas dapat dilihat bahwa, pengaruh pemberian pupuk NPK terhadap jumlah anakan pada tanaman seledri (Apium graveolens L.) terlihat berpengaruh yaitu pada perlakuan $\mathrm{P} 0$ (kontrol) jumlah anakan pada ulangan I terlihat sangat sedikit dibanding dengan perlakuan P1 (5g/tanaman) dan P2 (10g/tanaman). Namun jumlah anakan terlihat pada perlakuan P2 (10g/tanaman) pada ulangan ke 2 (7 anakan). Maka dalam penelitian ini sangat direkomendasikan penggunaan pupuk NPK dengan dosis $10 \mathrm{~g} /$ tanaman.

\section{Berat Panen (g)}

Hasil pengamatan dari berat panen (g) dihitung pada saat panen umur 8 MST dapat dilihat pada Tabel 6 dibawah ini.

Table 6. Berat Panen (g)

\begin{tabular}{lcccc}
\hline \multicolumn{1}{c}{ Perlakuan } & Ulangan I & Ulangan II & Jumlah & Rataan \\
\hline P0 (Kontrol) & 3 & 5 & 7 & 4,66 \\
P1 (5g/tanaman) & 4 & 7 & 11 & 7,33 \\
P2 (10g/tanaman) & 4 & 7 & 13 & 8,66 \\
\hline
\end{tabular}

Keterangan : Data pengamatan masing-masing ulangan I dan Ulangan II pada setiap pengamatan diambil nilai rata-rata per tanaman

Pada Tabel 6 dapat dilihat bahwa pengaruh pemberian pupuk NPK terhadap berat panen pada tanaman seledri (Apium graveolens L.) terlihat berpengaruh yaitu pada perlakuan P0 (kontrol) berat panen (g) pada ulangan I terlihat sangat ringan dibanding dengan perlakuan P1 (5g/tanaman) dan P2 (10g/tanaman). Namun pada berat panen terlihat pada perlakuan P2 (10g/tanaman) pada ulangan ke 2 ( $20 \mathrm{~g}$ ). Maka dalam penelitian ini sangat direkomendasikan penggunaan pupuk NPK dengan dosis 10g/tanaman.

\section{KESIMPULAN}

1. Pada hasil pengamatan tinggi tanaman seledri menunjukkan angka tertinggi pada rataan total terdapat pada perlakuan P2 (10g/tanaman) dengan angka $(11,93 \mathrm{~cm})$ pada ulangan ke II dan untuk tanaman terendah terdapat pada perlakuan PO (kontrol) dengan angka $(8,36 \mathrm{~cm})$ pada ulangan ke I.

2. Pada hasil pengamatan jumlah daun seledri pada perlakuan P1 (5g/tanaman) P2 (10g/tanaman) menunjukkan jumlah daun yang sama pada Ulangan II dengan angka (6,5 helai) untuk jumlah daun yang paling 
sedikit terdapat pada perlakuan PO (kontrol) dengan angka (6,25 helai) pada ulangan ke I.

3. Pada hasil pengamatan jumlah anakan seledri menunjukkan jumlah anakan terbanyak pada perlakuan P2 $(10 \mathrm{~g} / \mathrm{tanaman})$ dengan angka $(8,66$ anakan) pada ulangan ke II dan untuk tanaman terendah terdapat pada perlakuan PO (kontrol) dengan angka (4,66 anakan) pada ulangan ke I.

4. Pada hasil pengamatan berat panen seledri menunjukkan berat panen pada rataan total terdapat pada perlakuan P2 (10g/tanaman) dengan angka (17,5 g) pada ulangan ke II dan untuk berat panen paling ringan terdapat pada perlakuan PO (kontrol) dengan angka $(4,5 \mathrm{~g})$ pada ulangan ke I.

\section{DAFTAR PUSTAKA}

Dalimartha, S. 2005. Tanaman Obat di Lingkungan Sekitar. Jakarta: Penerbit Puspa Swara.

Kaya, E. 2013. Pengaruh Kompos Jerami dan Pupuk NPK Terhadap NTersedia Tanah, Serapan N, Pertumbuhan dan Hasil Padi Sawah (Oryza sativa L.). Jurnal Budidaya Tanaman. Agrologia.

Lingga, P., Marsono. 2000. Penggunaan Pupuk. Jakarta: Penebar Swadaya.

Soewito, M. 1991. Bercocok Tanam Seledri Secara Hidroponik. Yogyakarta: Kanisius.

Sutrisna, N., S. Sastraatmadja., I. Ishaq. 2005. Kajian Sistem Penanaman Tumpangsari Kentang dan Seledri di Lahan Dataran Tinggi Rancabali, Kabupaten Bandung. Jurnal Pengkajian dan Pengembangan Tekhnologi Pertanian. 8(1):78-87.
Wahyunto, Heryanto, B. 2005. Sebaran Gambut dan Status Terkini di Sumatera (dalam CCFPI). 2005. Pemanfaatan Lahan Gambut Secara Bijaksana untuk Manfaat Berkelanjutan. In: Prosiding Lokakarya. Indonesia Programe. Bogor.39

Wahyunto, Subiksa, I G M. 2011. Genesis Lahan Gambut Indonesia. Balai Penelitian Tanah". Bogor. 3-14 hal. 